\section{Historien om det biologiske}

\section{menneske}

Poul Duedabl, Jens Toftgaard Jensen, Mikkel Leth Jespersen \& Bo Poulsen (Red.): Den jyske Historiker nr. 112: Biologismer, 2006, 160 sider, $140 \mathrm{kr}$.

Det velrenommerede tidsskrift Den jyske Historiker, der har base ved Historie på Aarhus Universitet, har denne gang kastet sig over videnskabshistorien. Nærmere bestemt de biologiske og antropologiske videnskaber i det 19. og 20. århundrede. Det er der kommet et godt og underholdende nummer ud af.

'Biologismer' er titlen på temanummeret $o g$ på den første artikel. Den er skrevet af Jes Fabricius Møller, der i 2002 afleverede en ph.d.-afhandling ved Historie i København om dette emne. Fabricius Møllers artikel fungerer som en introduktion, der klargør hvad der forstås ved begrebet: Biologismer er betegnelsen for en række teorier, der benytter biologiske ideer som grundlag for forståelsen af verden; på både naturens og kulturens område. Biologisme-tænkningen havde sin storhedstid mellem Darwins popularisering af evolutionslæren i 1859 og opdagelsen af nazisternes koncentrationslejre i 1940'erne. De mest berygtede biologismer er den videnskabelige racisme, eugenikken (racehygiejnen), socialdarwinismen og kriminalbiologien, der alle skelnede mellem mere og mindre udviklede og værdige mennesketyper og i forlængelse heraf havde store poli- tiske konsekvenser. Biologismerne legitimerede imperialisme, tvangssterilisering, internering af afvigere og i deres yderste konsekvens drab af 'uværdige' liv i Det tredje Riges gaskamre. Derfor blev de biologiske tolkninger af samfundet og kulturen lagt på hylden efter krigen, mens socialkonstruktivismen vandt frem. Begrebet 'biologisme' er tæt beslægtet med scientisme og dukkede op omkring 1900 som et skældsord, der betegner en reduktionistisk teori, som hævder at kunne underordne al viden under én metode eller ét princip. Et forkætret eksempel på dette er den tyske darwinist Ernst Haeckels monisme, der gjorde naturvidenskaben til en slags erstatningsreligion.

Fabricius Møller redegør tillige for biologismens notoriske skamstøtte, eugenikken. Det pointeres, at tvangssterilisering af afvigere $i$ lige så høj grad var en socialdemokratisk som en højreradikal idé. De nordiske velfærdsstater blev således opbygget parallelt med indførelsen af steriliseringslove i 1930 'erne. I dag er racehygiejnen heller ikke så fjern, som vi måske forestiller os. Indførelsen af fri abort og fosterdiagnostik betyder, at vi nu selv, i stedet for staten, fravælger uønskede liv. Eugenikken er således blevet internaliseret, slår $\mathrm{Fa}$ bricius Møller fast.

I den følgende artikel 'Store huse af sten fra middelalderens Afrika' beskæftiger Mikkel Leth Jespersen sig med tolkningen af Great Zimbabwe, et ruinkompleks $i$ det indre Afrika. 
De europæiske videnskabsmænd, der undersøgte det, lå under for den sociokulturelle evolutionisme, som understregede, at afrikanerne var blandt verdens primitive og 'historieløse' folk. Derfor måtte de fundne bygningsværker være skabt af folk udefra. Sikkert bibelske eller antikke folkeslag. Da det i 1906 dokumenteredes, at de faktisk var bygget af afrikanere omkring år 1400, miskrediteredes i stedet bygningernes arkitektoniske værdi. Den sorte race kunne pr. definition ikke bygge pragtfulde huse. Omvendt bliver ruinerne i dag brugt til at afstive selvtilliden med i Zimbabwe, der identificerer sig med den glorværdige historie, ruinerne vidner om.

Poul Duedahl beretter herefter om raceantropologien i Danmark. Historien begynder dog internationalt. I midten af 1800-tallet kæmpede europæiske antropologer for at få deres videnskab anerkendt. De benyttede kvantitative metoder, såsom måling af kranier og næser, til at fremme disciplinens anseelse. Det lykkedes, og i 1855 etableredes det første professorat i antropologi i Paris. Raceantropologien var udpræget racistisk og rangordnede de forskellige racer efter udviklingstrin. I slutningen af 1800tallet fik den vind i sejlene og blev da indordnet i det evolutionære paradigme, der tolkede de ikke-europæiske racer som mellemstadier mellem aber og hvide mennesker.

I Danmark var der fra midten af 1800-tallet interesse for den fysiske antropologi. Det kulminerede i 1869, da den fjerde internationale kongres for arkæologi og antropologi blev holdt i København under stor mediebevågenhed. Universitetet havde dog ikke midler til en lærestol i antropologi, og disciplinen forblev en bibeskæftigelse for zoologer og læger. Den vigtigste danske raceantropolog var politilægen Søren Hansen, der målte tusindvis af kranier og udgav internationale artikler om de fysiske kendetegn ved grønlændere, indianere, forbrydere og fortidsdanskere. I 1904 stod han bag Den antropologiske Komité, der støttet af staten igangsatte opmålingen af 4.000 danskeres kranier, der var det vigtigste element i bestemmelsen af racepræg. Én af konklusionerne på dette arbejde var, at neanderthalmanden var forfader til den moderne dansker! Komitéen undersøgte også landets dårlige raceelementer, såsom åndssvage og sindssyge, og var herved med til at legitimere de steriliseringslove, der indførtes fra 1929.

Københavns Universitet indviede $\mathrm{i}$ 1938 Institut for Arvebiologi og Eugenik. Hermed havde raceantropologien og racehygiejnen fundet akademisk fodfæste. Succesen varede dog kort, da FN efter krigen tabuiserede den biologiske opfattelse af mennesket. FN's organisation for uddannelse, videnskab og kultur, UNESCO, sanktionerede en kulturel forståelse af mennesket og bandlyste racebegrebet til fordel for etniske og dermed kulturelle kategorier. Mens racismen er 
væk, fastlåses etniske minoriteter og oprindelige folk nu i en multikulturalistisk spændetrøje: De opfattes ikke som selvstændige individer, men som bærere af en bestemt kultur.

Pernille Sonne beskæftiger sig efterfølgende med en afart af den fysiske antropologi, kriminalbiologien, der søger at forklare kriminel adfærd biologisk. Faderen til disciplinen er italieneren Cesare Lombroso, der i 1880'erne diagnosticerede en særlig forbrydertype med bestemte fysiske kendetegn, der skyldtes atavistisk degeneration. I Danmark var den førende kriminalbiolog lægen Christian Geill, der omkring 1900 undersøgte danske forbrydere og konkluderede, at kriminalitet ofte kan grundes i fysisk, åndelig og moralsk degeneration. Han modificerede dog sit biologistiske standpunkt ved tillige at hævde miljøets betydning. De degenererede, der var kendetegnet ved f.eks. vigende pande, flyveører og uldagtig hårvækst på kroppen, kunne $\mathrm{i}$ nogle tilfælde reddes gennem en god og sund opvækst. Politisk betød kriminalbiologien, at straffeloven af 1930 skelnede mellem forskellige typer af forbrydere og indførte internering af psykopater og sædelighedsforbrydere, der blev anset for at være biologisk belastede. Denne lov skal ses i forbindelse med sterilisationslovene, der inkluderede muligheden for løsladelse af sædelighedsforbrydere, hvis de lod sig kastrere. Den tidsubestemte forvaring blev afskaffet i 1973, hvor socialkonstruktivismen vandt frem på bekostning biologien i forklaringen af kriminel adfærd. Vi finder dog stadig kriminalbiologiske ansatser i dag. $\mathrm{Ny}$ forskning viser for eksempel en sammenhæng mellem diagnosen ADHD og kriminalitet og en større tendens til psykisk afvigelse hos indsatte end hos normalbefolkningen. Biologien og medicinen spiller således igen en vigtig rolle i forståelsen af kriminalitet.

Anne Katrine Gjerløff, der i 2005 afleverede en ph.d.-afhandling ved Københavns Universitet om palæoantropologiens (studiet af fortidsmennesker) historie i Danmark, dokumenterer i 'Det gode, det onde og det grusomme - menneskelig aggression og evolution', hvordan vores tolkning af palæoantropologiske fund er farvet af tidens menneskeopfattelse. I tiden efter Første Verdenskrigs blodbad og frem til 1960'ernes Kolde Krig og atomtrussel blev fortidsmennesket opfattet som en blodtørstig og aggressiv jæger. Menneskehedens blodstængte historie kunne forklares biologisk: Artens overlevelse skyldtes dets aggressive natur. I 1970'erne vandt feminismen frem. Dræberaben blev afløst af Hippieaben, som Gjerløff træffende skriver (s. 108). Fokus var nu på kvinden som samler og ikke på manden som jæger, og artens overlevelse skyldtes snarere sociale færdigheder end aggressiv adfærd. Gjerløffs spændende historie er et godt eksempel på, hvordan videnskaben er farvet af dens kulturelle kontekst.

Biolog og filosof Theresa Schilhab 
udfolder herefter en videnskabsteoretisk kritik af naturvidenskabelig bevidsthedsforskning. Hun problematiserer forudsætningerne for den såkaldte 'spejltest', der af komparative psykologer benyttes til at bevise selvbevidsthed hos dyr. Testen, der går ud på at lade dyr se i et spejl og spore om de genkender sig selv, blev introduceret af Gordon G. Gallup i 1970'erne og er blevet meget populær blandt forskere. Problemet med testen er ifølge Schilhab, at den hævder objektiv gyldenhed, men i virkeligheden er antropocentrisk. Testresultaterne viser, at chimpanser og orangutanger har selvbevidsthed, ligesom mennesker, mens gorillaer, laverestående aber og andre dyr ikke har det. Imidlertid defineres selvbevidsthed i forsøget ud fra den måde, vi mennesker forstår selvbevidst adfærd på og giver ikke plads til andre bevidsthedsbegreber. For eksempel tolkes gorillaens dårlige resultater i spejltesten som et tegn på manglende selvbevidsthed, fordi den ikke reagerer på, at den ser en farveplet på sit øre i spejlet. Måske skyldes dens manglende reaktion blot, at den ikke er lige så forfængelig som mennesket og chimpansen. Omvendt tolkes duens gode resultater $i$ en modificeret spejltest ikke som selvbevidst adfærd. Schilhab problematiserer den naturvidenskabelige bevidsthedsforsknings fundament ved at pointere, at selvbevidsthed ikke kan bestemmes ud fra observation af menneskelignende adfærd. Hun angriber også de komparative psykologers 'naivrealistiske' videnskabsforståelse, der gør det nødvendigt for dem med en metode som spejltesten, der kan hævdes at være en naturvidenskabelig metode med objektiv gyldighed. Spejltesten bruges således til at legitimere deres arbejdes naturvidenskabelige værdi. Schilhab konkluderer, "at alle videnskaber (også naturvidenskaben) altid bygger på uudtalte teorier og forforståelser, i hvis lys resultaterne legitimeres." (s. 127)

Temanummeret rundes af med Mads Wanecks artikel om den socialistiske kritik af neodarwinismen i 1970'ernes Danmark. I det socialistiske tidsskrift for naturvidenskab Naturkampen (1976-91) kritiserede økologer og biologer neodarwinismen for at ligge under for den kapitalistiske ideologi. Blandt de højeste røster i dette kor var biokemikeren Jesper Hoffmeyer, der siden har gjort sig kendt ved en semiotisk kritik af neodarwinismen.

Politisering af naturvidenskaben har i det hele taget været et udbredt fænomen i videnskabshistorien. Det kommer dette temanummer på fremragende vis rundt om ved at fokusere på et af de mest sprængfarlige områder, evolutionsbiologien, hvis historie viser, at naturvidenskab nok er nødvendig, men ikke uskyldig.

Nummeret afsluttes med en artikel uden for tema. Tea Sindbæk skriver om den jugoslaviske historieskrivning efter Anden Verdenskrig. Det beskrives, hvordan historiografien 
efter Titos død i 1981 og op til Jugoslaviens sammenbrud begyndte at fokusere mere på ofrene for de interne konklifter mellem serbere og kroater. Det ville have været interessant med en antydning af denne antagonistiske historieskrivnings betydning for Balkankrigene i 1990'erne.

'Biologismer' kan i sin helhed varmt anbefales. Her er meget at hente for folk med interesse i dansk idé- og videnskabshistorie.

\section{Hans Henrik Hjermitslev}

\section{Kritik af den estetiske dom- mekraft}

Immanuel Kant: Kritik af den astetiske dommekraft. Oversattelse, noter, indledning samt efterfolgende essay ved Carsten Jubl $i$ Hafter for Gastfribed 6-7. Kobenhavn, 2006, 200 sider, $125 \mathrm{kr}$.

Den første del af Kants tredje Kritik (1790) foreligger nu i endnu en dansk oversættelse. Dermed udgør Carsten Juhls oversættelse af den nævnte første del med overskriften "Kritik af den æstetiske dømmekraft" samt Kants forord og indledning et delvist alternativ til Claus Bratt Østergaards oversættelse af den komplette Kritik af dommekraften (Det lille forlag 2005; anmeldt af undertegnede i Slagmark nr. 47). Til forskel fra kritikken af den teleologiske dømmekraft, som anden del af værket bringer, angår kritikken af den æstetiske dømme- kraft ikke den reale eller objektive formålstjenlighed $i$ naturen, men derimod den formale eller subjektive formålstjenlighed, som ikke bedømmes ved hjælp af forstanden og fornuften, men derimod "gennem følelsen af lyst og ulyst", som på ingen måde er relevant for erkendelsen af naturen eller af genstande i den, men som qua dømmende ud fra aprioriske principper (om formålstjenligheden) stiller en egen udfordring inden for Kants omfattende kritiske projekt, der som en propædeutik til filosofien overhovedet giver en udtømmende undersøgelse af det dømmende subjekt og samtlige dets erkendeevner, for så vidt som disse netop går ud fra eller er i stand til at gå ud fra aprioriske principper, om dette så bidrager til erkendelsen i egentlig forstand eller - som i de æstetiske dommes tilfælde - ikke.

Men hvad indbefatter en kritik af den æstetiske dømmekraft? Da den angår objektets formålstjenlighed $\mathrm{i}$ henseende til et dømmende subjekt, og denne formålstjenlighed ytrer sig i forholdet mellem erkendeevnerne, som er på spil i dømmekraften, og objektets form eller - som Kant siger, og som CJ oversætter direkte - uform (Unform), må kritikken af den æstetiske dømmekraft falde $i$ to tilsvarende hoveddele. Den første ('Det skønnes analytik') omhandler bedømmelsen af det skønne i smagsdommen og denne art dommes særlige egenskaber: Interesseløsheden med hensyn til objektets eksistens og deres iboen- 